\title{
Analysis of Self-Sufficiency for Seniors
}

A. Hudakova (Anna Hudakova)', L. Majernikova (Ludmila Majernikova)', A. Obrocnikova (Andrea Obrocnikova)', D. Magurova (Dagmar Magurova)', S. Andrascikova (Stefania Andrascikova) ${ }^{2}$, M. Oruc (Mirza Oruc) ${ }^{3}$, R. Zelenikova (Renata Zelenikova) ${ }^{4}$

1 Department of Nursing. Faculty of Health Care, Presov, University

\section{Original Article} of Presov in Presov, Slovakia.

2 Department of Midwifery, Faculty of Health Care, Presov, University of Presov in Presov, Slovakia.

3 Department of Nursing. Faculty of Medicine. University of Zenica, Bosnia and Herzegovina.

${ }^{4}$ Department of Nursing and Midwifery. Faculty of Medicine. University of Ostrava, Czech Republic.

\section{E-mail address:}

anna.hudakova@unipo.sk

\section{Reprint address:}

Anna Hudakova

University of Presov in Presov

Faculty of Health Care

Partizanska No 1

08001 Presov

Slovakia

Source: Clinical Social Work and Health Intervention $\quad$ Volume: $10 \quad$ Issue: 4 Pages:

Cited references: 22

\section{Reviewers:}

Pawel S. Czarnecki

Rector of the Warsaw Management University, Poland

Michael Costello

University of scranton school of education, USA

\section{Keywords:}

Self-sufficiency. Quality of Life. Facilities for Seniors. Physical performance. ADL test.

Disability.

\section{Publisher:}

International Society of Applied Preventive Medicine i-gap

CSWHI 2019; 10(4): 15 - 21; DOI: 10.22359/cswhi_10_4_04 @ 2019 Clinical Social Work and Health Intervention 


\section{Abstract:}

Background. Performance falls in old age and the onset of chronic diseases is developing a series of malfunctions and consequently there is impaired self-sufficiency and dependence.

Objective. The aim of this work was to determine how perceived self-sufficiency and quality of life among seniors in the institutional facilities.

Methods. We selected in this work a sample of 386 probants with standardized questionnaire surveyed the relationship of self-sufficiency and quality of life of the seniors population. Based on statistical comparisons, using Mann-Whitney Test.

Results. We found poorer self-sufficiency (gross score in the score 11, 65 ) in geriatric patients compared with residents in facilities for the elderly (gross score in the score 8, 92). Our study confirmed a clear dependence on the level of self-sufficiency and quality of life of seniors ( $p$ $<.001)$. ADL test has being identified in the region of Presov from the group of 1,028 seniors 65 years and older 149 probants who completed the test insufficiently.

Conclusions. Recommendations contained in the ADL tests, balance tests and others are part of a comprehensive geriatric assessment. The quality of life of seniors is an important indicator of their care.

\section{Introduction}

Prolongation of human life is associated with higher morbidity and functional disability (1). For dizabilite is an important measure of residual sovereignty (2). Self-sufficiency of the individual is conditioned by two factors: functional state of the environment and demands. Many individuals with severe disabilities are fully self-sufficient in quality high-end housing (lift, central heating, kitchen equipment, communication and availability below). Or barrier-free environment but dependent in harsh environments $(1,3)$.

The East Slovakia Region is one of the economically underdeveloped areas across the European Union. This status is reflected in the health and social fields. Social services are inadequate in terms of quality and scope, institutional care is limited, senior financial options are restricted (4). These aspects mainly influence the the quality of life and the senior population.
Increasing age and the presence of chronic diseases influence the whole series of functional defects what makes self-sufficiency worse and develops the dependence of handicapped individuals (5). Self-sufficiency can be easily detected by I-ADL Test (Instrumental Activity of Daily Living) that is already insufficient at an early state of functional defect; in the following period the absence of basic daily activities comes along with what we find out from the ADL Test (Activity of Daily Living) (6).

\section{Aim of research}

The aim of this research was to evaluate the proportion of relation quality of life from the self- sufficiency in basic daily activities of patients hospitalized in geriatric departments and residents in facilities for the elderly. We supposed that the level of self-sufficiency of geriatric patients and residents in facilities for the elderly statistically differs and is an important factor of 
their subjective evaluation of their own life quality.

\section{Methodology of Research}

Altogether 204 patients of Geriatric Department of Faculty Hospital J. A. Reiman Presov and 182 residents of Facility for the elderly in Presov (Slovakia) took part in survey. The whole sample contained 386 respondents. In our survey we used causal - comparable research. For selecting individual components we used in research the method of gaining the information with the help of two batteries of standardized tests - test of self-serving daily activities ADL (Barthel Test standardized self-judging scale that finds out the level of managing self-serving activities performed daily; the value of Crombach alpha of used method moved between the interval of $0,8217-0,9122$ for individual items). For statistical comparison of surveyed groups we used the test for two independent selections of the Mann-Whitney Test. This unparametrical method enabled us to find out statistically the major differences between the groups in researched parameters.

\section{Results}

The senior population assessed their quality of life, especially in terms of the per- ception of their health status. Therefore we were interested in the representation of the largest health problem in the study groups (Table 1).

The graphic view is clear that the severity of priority health problems are heart disease (65 geriatrics patients and 36 seniors). This is connected with the fact that cardiovascular disease can „keep“ the primacy in the prevalence of disease in Slovakia. The high representation of musculo-skeletal system in this age group (61 geriatric's pacients and 50 seniors) confirms our assumption that mobility is a major domain of quality life of geriatric patients and seniors. We also investigated the perceptions of quality of life in both groups. Here are the results of the examination of significant differences between the groups in overall quality of life (Table 2).

We can conclude from the above results $(p<.001)$ that in the population group for senior citizens is manifested a gross score significantly higher overall quality of life associated with a health group than in geriatric patients. We see cause that unlike residents in facilities for seniors dominated in geriatric patients actual health complications and unresolved possibilities of life perspective (who will take care of them after their release, the rate of self-sufficiency, etc.).

Table 1 Comparison of the biggest health problem

\begin{tabular}{|l|c|c|}
\hline & Geriatric patients & Facility for seniors \\
\hline Cardiac disease & 65 & 36 \\
\hline Foot pain & 61 & 50 \\
\hline Other problems & 96 & 78 \\
\hline
\end{tabular}

Table $\mathbf{2}$ Statistical results of surveys differences in the value of the gross score WHOQOL - BREF found in the Mann - Whitney Test.

\begin{tabular}{|l|c|c|c|c|c|}
\hline & \multicolumn{2}{|c|}{ Geriatric patients } & \multicolumn{2}{c|}{ Facility for seniors } & \\
\hline The variable & M & SD & M & SD & Z \\
\hline The gross score & 74,32 & 15,46 & 85,08 & 11,37 & $-7,371^{* * *}$ \\
\hline
\end{tabular}


We list the results of surveyed groups in self-sufficiency according to ADL Test. The values are evidently different in all tested items - toilette, food income, dressing, appearance, mobility and bathing (Table 3 ).

From the results in Table 1 it is obvious that there is a major dependence of level of self- sufficiency from the life quality of seniors $(p<.001)$. On the basis of stated facts we can say that the correlative relationships of both groups among evaluated parameters have comparable power and direction.

\section{Discussion}

The stated results prove our supposition that increasing deficit of self-sufficiency causes the decline of life quality of geriatric patients and of residents in facilities for the elderly. That means that their correlative relationship is negative.

In our research we found that the diminished self-sufficiency (rough score with ADL Test, score 11, 65) with geriatric patients in comparison to residents of facilities for elderly (rough score with ADL Test, score 8,92 ). Our results proved that the less self-sufficient are especially hospitalized geriatric patients in comparison to clients of institutions for seniors. Self-sufficiency is another important trait elderly people cherish. Self-sufficiency will, in time, give an elderly person self-confidence while self-confidence leads to an increased feeling of self-worth. Self-worth is being defined as: "the sense of one's own value or worth as a person", leading towards an increased mental health and greater sense of purpose in life (4). The elderly can feel like they are a burden to the household they share with younger generations, especially if they are suffering from disabilities preventing them from active participation in the household. Other elements potentially contributing to this feeling include but are not limited to a financial burden; occupying space in a small living area; requiring a lot of time and effort. The feeling of being a burden on family members causes stress as well as feelings of unhappiness. The Committee on a National Agenda for the Prevention of Disabilities (NAPD) conceptualized a model for disability; which contains a person's physical or mental limitations; in interaction with physical and social barriers in the environment; prevent the person from taking equal part in the normal life of the community (22). That is why within care giving and rehab care we stimulate the patients into active participation on recovery regime instead of position of passively accepting help (20).

ADL Test should be the main functional test for disclosing self-sufficiency (or lack of it) with geriatric patients and support of their self-sufficiency should be the domain of geriatric care givers. Positive tasks can play various compensation aid gadgets for

Table 3 Statistical results of search of differences between both groups found out by Mann - Whitney Test

\begin{tabular}{|l|c|c|c|c|c|}
\hline & \multicolumn{2}{|c|}{ Geriatric patients } & \multicolumn{2}{c|}{ Institutions for seniors } & \\
\hline Parameter & $\mathrm{M}$ & $\mathrm{SD}$ & $\mathrm{M}$ & $\mathrm{SD}$ & $\mathrm{Z}$ \\
\hline Toilette ADL & 2,00 & 1,36 & 1,48 & 0,97 & $-4,264^{* * *}$ \\
\hline Food income ADL & 1,66 & 1,05 & 1,16 & 0,41 & $-5,283^{* * *}$ \\
\hline Dressing ADL & 1,83 & 1,12 & 1,25 & 0,52 & $-5,557^{* * *}$ \\
\hline Appearance ADL & 2,02 & 1,10 & 1,61 & 0,81 & $-3,658^{* * *}$ \\
\hline Mobility ADL & 2,64 & 1,45 & 2,33 & 1,48 & $-2,541^{* *}$ \\
\hline Bathing ADL & 2,08 & 1,08 & 1,63 & 1,02 & $-2,541^{* * *}$ \\
\hline ADL rough score & 11,65 & 5,82 & 8,92 & 3,53 & $-4,885^{* * *}$ \\
\hline
\end{tabular}


Table 4 Summary ADL test result

\begin{tabular}{|c|c|c|c|c|c|c|c|c|}
\hline \multicolumn{9}{|c|}{ Barthelovej Test (women and men) } \\
\hline Age & 65-69 a. & 70-74 a. & 75-79 a. & $80-84$ a. & $85-89$ a. & $\begin{array}{c}\text { Over } 90 \\
\text { a. }\end{array}$ & $\begin{array}{c}\text { Together } \\
\%\end{array}$ & $\begin{array}{l}\text { Together } \\
\text { numb. }\end{array}$ \\
\hline Sumar of prob. & 347 & 306 & 178 & 132 & 44 & 21 & & 1028 \\
\hline $\mathrm{n} \%$ of number & $34 \%$ & $30 \%$ & $17 \%$ & $13 \%$ & $4 \%$ & $2 \%$ & & \\
\hline over $80 \mathrm{p}$. & 330 & 280 & 151 & 88 & 23 & 7 & $85,5 \%$ & 879 \\
\hline $80-61 \mathrm{p}$. & 12 & 12 & 17 & 19 & 11 & 4 & $7,3 \%$ & 75 \\
\hline 60-41 p. & 2 & 5 & 4 & 17 & 2 & 2 & $3,1 \%$ & 32 \\
\hline $40-0 \mathrm{p}$. & 3 & 9 & 6 & 8 & 8 & 8 & $4,1 \%$ & 42 \\
\hline$\%$ over $80 \mathrm{p}$. & $95 \%$ & $92 \%$ & $85 \%$ & $67 \%$ & $52 \%$ & $33 \%$ & & \\
\hline$\% 80-61 \mathrm{p}$. & $3 \%$ & $4 \%$ & $10 \%$ & $14 \%$ & $25 \%$ & $19 \%$ & & \\
\hline$\% 60-41 \mathrm{p}$. & $1 \%$ & $2 \%$ & $2 \%$ & $13 \%$ & $5 \%$ & $10 \%$ & & \\
\hline$\% 40-0 \mathrm{p}$. & $1 \%$ & $3 \%$ & $3 \%$ & $6 \%$ & $18 \%$ & $38 \%$ & & \\
\hline
\end{tabular}

increasing self-sufficiency of patients in all its areas (8). For maintaining the adequate physical capabilities it is necessary to provide for seniors various mobility activities by the form of every day exercises and common mobility programs. Equally important is the psychical support of seniors who are from the point of their age and functional conditions always a risk group for medicine and care giving $(1,7)$.

Other authors identified the ADL Test (Activity of Daily Living according to Barthel's) in the Region of Presov from the group of 1,028 seniors 65 years and older 149 respondents who completed the test insufficiently $(10,19)$. After the approval of these 149 respondents there were home conditions were evaluated according to the questionnaire prepared by Tideiksaar (with medium modification). Up to 42 (22\%) subjects had bad and inadequate home conditions. It is well known that the quality of home conditions for patients with insufficient abilities to carry out routine daily activities determines the need of home or institutionalized care. The 1,028 respondents were assessed with the consent of the ability to perform normal daily activities according to the ADL Test. Table 4 shows the summary results of the test on ADL Test respondents examined.
The vertical columns are the age zone (after 5 years), horizontal columns are the results, which reached probands (in absolute terms and percentage terms). The last two vertical columns show summary results of the Test. A full score achieved by the Bartel Test is 100 points. According to the literature the easy default value of 61 points or more was deemed a moderate disturbance obtaining 41 to 60 points and 40 points suffer from severe and less $(9,18)$.

Recommendations contained in the ADL Tests, Balance Tests, and others are part of a comprehensive geriatric assessment (8, 10). Decreases with age and physical ability and consequently appear as attribute dependence together with an increasing risk of disability, frailty and injuries. The patient has the right to a functional signaling to resolve their biological, psychological and social needs. Alternative versions for hospital signaling could be personal property for the elderly at home and in the social facilities. Service emergency care is provided on a contractual basis and the precondition of fixed telephony in the home client that is secure signaling (placed on the wrist or neck) and pushes the button, as appropriate (11, 12). In the literature we did not encounter the assessment of housing conditions in the elderly with functional deficits. Nemeth et 
al found (in research) that $22 \%$ of the functionally disabled elderly had poor housing conditions (10). In Linz (Austria) in the 61-70 group, $70 \%$ reported annual (at interview) very good housing conditions; $23 \%$ satisfactory; only $7 \%$ of poor housing conditions, for self-sufficient seniors (13). The efforts of family members to take care of his old functionally disabled member (as it was in our group) lives a burden. Already 30 years ago Gressner, Nestor Slovak gerontology asked for these families increased care and pointed out the necessity of overprotection for these selfless caregivers (12).

\section{Conclusion}

Prohaska et al made important observations in the elderly and he assessed the reasons for their action of negative factors on physical activity and the consequences of their deterioration. He found that the lowest levels of physical activity often present lower socio-economic status individuals (14). Physical dependence can be tested for seniors with ADL and IADL Tests. In several foreign sources in other studies nursing is a recommended functional status questionnaire (FAQ) $(15,16)$. Seniors at home show a higher degree of self-sufficiency as seniors living in social facilities. This is confirmed by Cagankova et al research implemented in Zlin in the sample of 200 seniors aged over 80 years (17). According to research Nemeth in order to determine disability in Presov was statistically the greater female population is represented as an independent (in the group of moderate, depending on the level of $p$ $<0.01)$. Expected life of the elderly population of our century requires maintaining an active life and help prevent disability (4, 21). Nursing interventions can prevent disability for older people.

\section{Author contributions:}

AH: manuscript writing, literature search, critical review of the manuscript; LM: literature search, critical review of the manuscript; AO: literature search, critical review of the manuscript; DM: critical review of the manuscript; SA: critical review of the manuscript.

\section{Conflict of interest statement:}

The authors state that there are no conflicts of interest regarding the publication of this article.

\section{Bibliography}

1. HEGYI L, KRAJCIK S (2015) GERIATRICS FOR GENERAL PRACTITIONER Bratislava Herba p 408.

2. EVANS JG et al (2000) Oxford Textbook of Geriatric Medicine, Oxford UP, p.17 -18.

3. HUDAKOVA A et al (2016) Geriatric syndromes as predictors of Nursing in geriatrics. Presov University of Presov 192 p.

4. KHAN MN, MONDAL MNI, HOQUE N, ISLAM MS, SHAHIDUZZAMAN M (2014) A study on quality of life of elderly population in Bangladesh American Journal of Health Research 2(4), p. 152-157.

5. BAYLISS EA, EDWARDS AE, STEINER JF, MAIN, DS (2008) Processes of care desired by elderly patients with multimorbidities Family Practice, August 1, 25(4), p. 287 $-293$.

6. CURLESS W et al. (2003) Pain in Geriatric Cancer Patients In. The Journal of Supportive Oncology. Vol. 1, N. 3. 2003.

7. SHERWOOD G, BARNSTEINER J (2012) Quality and Safety in Nursing In. A Competency Approach to Improving Outcomes Wiley-Blackwell, pp. 432.

8. DAINTY P (2007) Comprehensive Geriatric Assessment In. Review. Br J Hosp Med. 68 (8), p. 133-135.

9. SHELKEY M, WALLACE M (1999) Katz Index of Independence in Activities of Daily 
Living Geront Nursing 25(3), p. 8-9.

10. NEMETH F, DERNAROVA L, HUDAKOVA A (2011) Comprehensive Geriatric Assessment, Presov. Datapress, p. 216.

11. Senior Assistance Management reliable and trustworthy partner [online] [cit.2019/01/26] Available on http://www.seniorasistencia. sk/showdoc.do?docid=70.

12. HEGYI L, KRAJCIK S (2010) Geriatria Bratislava. Herba 2010, pp. 46-48.

13. VAZANSKA M (2010) Attributes of the elderly's life with regard to the transformations of company [online] [cit.2018/12/22] Available on http://www.pulib.sk/elpub2/ FF/Balogova1/pdf_doc/26.pdf.

14. PROHASKA $T$, BELANSKY $E$ et al. (2006) Physical activity public health and aging critical issues and research priorities. J Gerontol B Psychol Sci Soc Sci. 2006, 6 p. 267-273.

15. BOYD M A (2008) Psychiatric Nursing Comtemporary Practice 4th ed. Philadelphia Wolters Kluwer Lippicott Williams\&Wilkins, 2008, 952 p.

16. FLETCHER K (2008) Nursing Standard of Practice Protocol Recognition and Management of Dementia Hartford Institute for Geriatric Nursing. [online] [cit. 2018-1218] Available on http://www.Consultgerirn. org/topics/dementia/want_to_know_more.

17. CAGANKOVAA (2010) $\overline{\text { Self-sufficiency of }}$ seniors over 80 years in home and social facilities Nurse, 20, 12, pp. 40-42.

18. McAULEY E, KONOPACK JF, MORRIS KS, MOTL, RW et al. (2005) Physical activity and functional limitations in older women J Gerontol B Psychol Sci Soc Sci. 60, pp.901-909.

19. HAYVOOD KL, GARRATT AM, FITZPATRICK R (2007) Older people specific health status and quality of life: a structured review of self-assessed instruments Journal of Evaluation in Clinical Pravtice, 11, 4, p. 315-327.

20. SUTTON M, GRIMMER-SOMMERS K, JEFFIRIES L (2008) Screening tools to identify hospitalised elderly patients at risk of functional decline J Clin Pract. 62, 12, p. 1900-1909.

21. SCHEEL ME, PEDERSEN BD, ROSENKRANDS V (2008) Interactional nursing - a practice-theory in the dynamic field between the natural, human and social sciences Scand J Caring Sci. 22, p. 629-636.

22. POPE AM, TARLOV AR (1991) Disability in America toward a national agenda for prevention. Washington DC National Academy Press, p. 287. 